\title{
Optimum Use of Nonmonetary Inputs for Sustainability in Agriculture
}

\author{
Urjashi Bhattacharya $^{1 *}$, Smritikana Sarkar ${ }^{2}$ and Pintoo Bandopadhyay ${ }^{3}$ \\ Department of Agronomy, Bidhan Chandra Krishi Viswavidyalaya, \\ Mohanpur, Nadia-741252, West Bengal, India \\ *Corresponding author
}

\begin{abstract}
A B S T R A C T
\section{Keywords}

Conservation,

Environment,

Agro-ecosystem,

Sustainability,

Non-monetory

Article Info

Accepted:

10 March 2020

Available Online:

10 April 2020

Natural resources are being consumed at an alarming rate, and the capacity of resources and technologies to satisfy food demand for the growing population remains uncertain. Since agriculture along with its allied sector, is the largest source of livelihood in India having $70 \%$ of rural household depending on agriculture as their primary occupation of which $82 \%$ of farmers are small and marginal (FAO, 2019), the use of non monetory inputs by the poor farmers can be quite the most feasible, eco-friendly and climate smart option to preserve the environment and safeguard the natural resources. Non monetory inputs are that locally adaptable cultural operation which helps in getting more yield without any extra cost and whose cost never change with the level of output.
\end{abstract}

\section{Introduction}

Agriculture along with its allied sector, is the largest source of livelihood in India.70\% of rural household depends on agriculture as their primary occupation of which $82 \%$ of farmers are small and marginal (FAO,2019). Intensive cultivation has already compromised the sustainability of the agroecosystem and uncertainties of climate now days calls for changes in the input intensive practices in agriculture.

So focus on alternative approaches to feed ever increasing population should be such that it can combat poverty and climate change hand in hand along with improving the sustainability of the system. The use of non monetory inputs by the poor farmers can be quite the most feasible, eco-friendly and climate smart option to preserve the environment and safeguard the natural resources of agro-ecosystems which has almost become mandatory

Non monetory inputs are those locally adaptable cultural operations which helps in getting more yield without any extra cost and the cost never change with the level of output. Some of the non-monetory inputs are: 
Conservation tillage

Sowing

Plant population

Organic mulching

Choice for crops

Pest and disease management

Weed management

Advisory support

Use of non-monetory inputs is important for agriculture because:

1. The first green revolution in the 1960's was aimed to increase the agricultural productivity with higher levels of inputs like fertilizers, pesticides, use of farm machinery etc.

2. No doubts with excessive levels of these inputs we have achieved the objective to feed our ever increasing population which is expected to hit 9.7 billion in 2050 (FAO, 2019) but in the process for short term improvement various forms of ecological stresses like loss of biodiversity in agricultural lands, salinization, alkalization, nitrate pollution in groundwater, pesticide residues in food etc. have aggravated the situation more.

3. Intensive or high input agriculture uses higher levels of machinery, chemicals, labour, capital etc to maximise produce. Hence affecting environment in multiple ways like:

-Soil and water pollution due to excessive use of chemicals and fertilizers.

-Heavy use of pesticides killing beneficial organisms and affecting biodiversity of the ecosystem.

- Soil erosion and land degradation due to use of heavy machinery and tillage implements.

- Exploitation of fossil fuels for various cultural operations and adding to greenhouse gases.
4. So new alternatives for agricultural production which would integrate both biological and ecological processes in the wake of devastating climate change should be the urgent need of the hour.

5. Due to intensive cultivation the inherent capacity of land to produce more has been disrupted and natural resources like soil, water etc has been exploited to a dangerous level.

6. The use of costly external inputs should be minimized and substituted by optimum non monetory inputs which uses the knowledge and skills of farmers and manipulate the agro-ecosystem in such a way so that it can address the energy flow, nutrient cycling and resilience of the entire system as well as maintain system productivity in the long run (Pretty, 2008).

Sustainable agriculture is the efficient and profitable production of high quality food and fibre in a way that protects and improve the natural environment, social and economic conditions of farmers and their local communities while safeguarding the health and welfare of all farmed species so as to ensure the attainment and continued satisfaction of human needs for present and future generations.

The production system is called sustainable if outputs of all products harvested are balanced by inputs back to the system.

\section{Non-monetory inputs}

\section{Conservation tillage}

Due to late onset of monsoon nowadays kharif crops like rice is being late sown which leads to late harvesting and hence causing a very short turnover period for sowing of next rabi crop like wheat, lentil etc and thus hampering their yield drastically (Singh and Kaur, 2012). 
When cropping intensity in a year is increased less time for land preparation between two crops makes it mandatory for farmers to go for conservation tillage practices. For eg: Kharif paddy (July/August- October/ November) - Lentil (mid October/Mid November- late February/early March)Summer Maize (late February / MarchMay/June).Here very little time is obtained for land preparation for lentil and maize sowing. Conventional tillage not only increases the cost of cultivation but also causes (Hobbs et al., 2008) soil erosion and degradation; reduced soil fertility, waterholding capacity, soil biological activity and contributes to greenhouse gases.

In short it has a negative impact on soil environment and its sustainability. Therefore in order to reverse the trend of natural resource degradation focus should be on resource conserving technologies like conservation tillage.

Conservation tillage: According to CTIC (The Conservation Tillage Information Centre, 1990 and 1995) "Any tillage or planting system that maintains at least $30 \%$ of the soil surface covered by residue after planting to reduce water erosion or where wind erosion is a primary concern, maintain at least 1000 $\mathrm{kg} / \mathrm{ha}$ of flat, small grain residue equivalent on the surface during the critical wind erosion period".

Due to different conservation tillage practices following benefits are observed a)Better aggregation and pore size distribution was observed in case of zero tillage (Bhattacharya et al., 2006); b) Better soil structure resulting in more water stable aggregates reduces soil crusting and erosion by allowing water and air to enter the soil thereby improving germination and seedling establishment (Lal et al., 1994); c) Water infiltration rate was higher in parmanent beds and zero tillage system than the conventional tillage. (Jat et al., 2009); d)Up to eight fold increase in hydraulic conductivity in zero tillage stubble retained have been reported over treatments where stubble was removed by burning (Valzano et al., 1997); e)Conservation tillage practices with crop residues on soil surfaces reduces evaporation rate and conserves soil moisture (Prihar et al., 1996); f)Accumulation of crop residues in the soil under zero tillage and minimum tillage results in more organic matter content and thereby improving the fertility of the soil; g) Highest soil respiration activity, soil dehydrogenase activity, and microbial biomass carbon has been observed in conservation tillage treatments as reported by Sharma et al., (2011) and Yeboah et al., (2016). Soil flora and fauna is responsible for stabilizing the soil structure and it's been reported to increase in the long term if conservation tillage is being practised (Singh et al., 1994). Moreover conservation tillage practices saves time, labour, fuel and reduces the cost of cultivation.

\section{Sowing}

\section{Sowing time}

Optimum sowing time have considerable effect on yield and productivity of crops. Different sowing time provides different environmental conditions like temperature, precipitation etc. which might not be favourable for the growth of a particular crop. So appropriate sowing time is important for ensuring good germination, timely appearance of seedling and better root development (Ganvit et al., 2019). Optimum sowing time varies according to crop, variety, agroclimatic zones etc. It is well known that if sowing of wheat is delayed beyond $25^{\text {th }}$ of November the yield reduction is expected to be $30 \mathrm{~kg} / \mathrm{ha} / \mathrm{day}$. (Directorate of Wheat development). Correct age of seedlings should be used for transplanting. For e.g. - 3- 
4 weeks old seedling for short duration rice. 5-6 weeks old seedling for long duration rice. A difference in sowing date has relatively improved the yield and yield attributes of wheat as reported by Singh et al., (2016).

\section{Sowing depth}

Optimum sowing depth is needed for good crop stand and higher yields (Ali and Idris, 2015).It has been reported by Alam et al., (2014) that differences in sowing depth has significantly improved the yield components of wheat. Depth of sowing varies with -

1. Crop: Optimum depth for most field crops is $3-5 \mathrm{~cm}$ but it varies from crop to crop. Like: Rice -3-4 cm, Maize-5-6 cm, Wheat-5-6 cm, Pearlmillet-2-4 cm.

2. Soil type: In sandy soils deeper sowing, whereas in heavy soil shallow sowing is recommended.

3. Moisture availability: In dryland condition crops should be sown in deeper layers.

4. Seed size: Bold seeded crop should be sown deeper (upto $10 \mathrm{~cm}$ ), small seeded crop should be sown upto $(3-4 \mathrm{~cm})$.

\section{Plant population}

Plant population is the total number of plants growing per unit area. Plant population has significant effect on growth and yield of crops. Plant population should not be so much higher that there is intraspecific competition for nutrients, soil moisture, light, etc. so that yield per unit area of the crop is hampered. Likewise it shouldn't be too low to achieve economic yield.

For indeterminate plants which are highly branching or tillering like rice, wheat etc higher plant population causes yield reduction due to reduction in number of seeds. For determinate plants which are non-branching and non-tillering like maize, sorghum the yield reduction is due to reduction in size of ears. For better crop stand, uniform growth and maturity, and finally for maximising yield optimum plant population is the main factor. To maintain optimum plant population following approaches should be taken: a) Preparation of proper seed bed; b) Arrangement of rows and beds; c) Maintenance of row spacing; d)Accurate planting time and methods; e) Seeds of good quality and health; f)Ensuring maximum germination percentage. It has been reported that uniform plant stand always have yield advantage than non-uniform plant stand (Caliskan et al., 2004).

Though a generalized optimum plant population can't be recommended since it depends on crops and their spacing, seasons, agro-climatic zones, soil fertility, water availability etc., Abuzur et al., (2011) reported there was difference in physiological parameters of maize according to difference in plant population.

\section{Organic mulching}

Technical term of mulch means' covering of soil'. Mulching is a practice of covering the soil or ground for soil and water conservation, in the process creating favourable conditions for plant growth, development and crop production. (Sharma and Bharadwaj, 2017)

Any locally available organic substance present in the field like dried leaves, straw, previous crop residues, stubbles, etc can be used by farmers for mulch purposes. These are eco-friendly as well as cost-effective.

Research results have shown that mulch plays an important role in improving physical, chemical and biological properties of the soil. 
The benefits of organic mulching are as follows: - Mulching helps in regulating the soil temperature. It has been reported that plant residues acting as mulch can reduce soil temperature by $8^{\circ} \mathrm{C}$ (Krenzer et al., 1987).

Different research results have shown that organic mulches covering the soil surface improves soil moisture by reducing evaporation, improving water infiltration and enhancing water retention capacity of soil (Lal, 1974). It was reported that soil moisture in mulched plots was not only higher but stable during the entire vegetation period (Sinkevičienè et al., 2009).

Water holding capacity of soil is increased due to organic mulches decomposition and humus formation ( $\mathrm{Ji}$ and Unger, 2001). Teame et al., (2017) have found that there are differences in soil moisture content availability owing to different soil depths after sowing.

High soil cover reduces surface runoff allowing more time for the rainwater to infiltrate. Hatfield et al., (2001) has reported there is a reduction of $34 \%-50 \%$ in soil water evaporation due to crop residue mulching.

Soil structure is improved due to presence of decomposed residues and humic substances in the soil which causes formation of better aggregates in soil thereby reducing compaction (Ibeawuchi et al., 2015).

Weed growth is suppressed by mulching since mulched layer excludes light. Without higher sunlight, young weeds cannot produce sugars needed for growth and ultimately die. Since some weed seeds require light in order to germinate, so mulch can also prevent germination. It has been shown that residues of small grains inhibit weed emergence and growth in cropping systems by allelopathy (Putman, et al., 1983, Blum, et al., 1997).
Organic mulching promotes soil fertility and soil health by acting as a source of all essential major and minor nutrients. Due to decomposition of organic mulches microbial activity is stimulated and thereby increasing soil organic matter and enhancing the availability of nutrients in the soil. (Kumar et al., 2017)

On overall organic mulching improves plant growth, increases yield and productivity of crops by sustaining the quality of soil.

\section{Choice of crops}

Choice of crops should be done in such a way so that it can maintain ecosystem diversity, fertility, resilience and at the same time enabling farmers to yield remunerative crops throughout the year. For example:

Monocropping should be completely avoided as it exhausts the soil fertility. Moreover autotoxicity in monocropping can be observed in crops like alfalfa, rice, pigeonpea, sunflower etc. This occurs due to allelopathic effect exhibited by accumulation of phytotoxins of root exudates and decomposing plant residues and multiplication of harmful pathogens in soil. (Narwal et al., 1998)

At least one leguminous crop should be incorporated in a cropping system so as to improve the soil fertility.

Exhaustive high feeding crops like rice, potato should be followed by restorative crops like cowpea, greengram, blackgram etc,

Perennial and long duration crops like sugarcane should be followed by seasonal crops like greengram, groundnut etc.

Deep rooted crops like cotton, should be followed by shallow rooted crops like lentil, 
potato etc. so that mining of nutrients takes place from different layers of soil so that nutrients are not exhausted from a particular single layer.

The crops of wet (anaerobic) soil should be followed by the crops of dry (aerobic) soil.

Eg: Rice-bengal gram / lathyrus / pulses / oilseeds. The tendency to build up difficultto-control weeds becomes less in such rotation than in continuous wet land rice culture.

Favourable intercrops/mixed crops so that farmers can manage more than one crop in the same field at the same time and the risk of failure of one crop can be compensated by better yield of the other crop. For eg: wheat+mustard, rice+pulse, potato+wheat etc.

The crops that are susceptible to soil-borne pests, pathogens should be followed by tolerant / trap crops. Eg: sugarcane-marigold for pathogenic nematodes.

Rotational use of cultural practices in addition to rotational cropping provides more and assured benefits than that of adopting only one crop.

Selection of crops by a farmer depends on a number of factors:

a) Agro-climatic conditions of the region: In regions where rainfall is higher crops like rice can be grown. Less water requiring crops like millets, pigeonpea, sorghum etc should be grown in dry areas. High feeding crops should be grown in soils having high fertility whereas leguminous crops like chickpea, lentil etc should be grown in poor fertile soils. In cold climates low temperature loving crops like wheat, mustard, lentil should be grown whereas in high temperature areas crops like sorghum, pearlmillet etc should be grown. b) Irrigation water availability: Areas where irrigation water availability is assured multiple cropping systems can be followed. Eg: Rice-potato-groundnut, rice-potato-jute.

c) Market demand: For example: Areas having high market demand for mustard oil farmers should cultivate mustard crop. Likewise a high market demand for vegetables commands the farmers to grow vegetables more.

d) The economic conditions of farmer: Rich farmers can go for high value crops like cocoa, tea, coffee plantations which require high maintenance, labour, skill and infrastucture. Whereas poor farmers can go for less value crops like rice pulses, wheat.

e) Cropping system options: Depending on the oppurtunities available farmers must decide whether to go for intercropping, mixed cropping, crop rotation, relay cropping etc.

f) Availability of post-harvest, storage and processing facilities: It depends on whether primary processing and storage facilities are available or not.

g) Appropriate government policies and schemes: It depends on government policies and schemes favouring a particular crop in the region and whether the farmers are eligible for it.

\section{Pest and disease management}

On the context of sustainable agriculture and growing awareness of food and environment quality it is quite imperative to find alternative solutions to keep pest population under control. Better understanding of bioecological relationships of cropping systems holds the key for more appropriate environment designs and skill-intensive ecofriendly management techniques so as to 
maintain balance in pest -predator population at the same time growing a healthy good quality crop.

Therefore switching from extensive use of pesticides to a more natural way of controlling pest population has become the need of the hour. Some of the practices which make the environment less attractive and favourable for the pest to survive, grow and reproduce are as follows:

Use of clean, disease free and certified seeds for sowing. Harvesting of potato tuber only after defoliation of leaves helps to prevent tuber rot due to late blight disease.

Preparation of clean main field and nursery bed by removing plant debris, deep summer ploughing, trimming of bunds etc so that pests and diseases of various stages can be obliterated.

Use of pest/disease tolerant varieties of crops. For example: Rice stem borer resistant variety- Jagannath, Ratna, VL-Dhan 61.Rice blast resistant variety-Jaya, Rasi .Wheat resistant variety for leaf rust and blight Karan Vandana.

Adjusting the time of sowing and harvesting to escape peak season or susceptible timeperiod for the infestation of pests and diseases. For ex.- Early sowing of chickpea in the month of October will show maximum damage of leaf by insects like Helicoverpa armigera and Spodoptera exigua whereas infestation is lowest when sown in January.(Sharma et al., 2016).

Pea and gram if immediately sown after rain when soil moisture levels and temperature is high there is high incidence of root rot, blight and wilt so it's recommended to sow them during the month of November and December. It has been observed by Hossain et al., (2009) that changing the dates of sowing can reduce the population of aphids and pod borers.

Diseases which spread very fast under higher plant density can be checked by wider spacing of crops. For Eg: Cercospora on pulses.

\section{Weed management}

In order to avoid chemical control of weeds as much as possible basic knowledge of biological and ecological characteristics of weeds is necessary. Diversifying crops and varying cultural practices will disrupt ecological niches of weeds (Liebman and Davis, 2000). To control weeds effectively by keeping harmony with crop environment the following measures can be followed:

Preventive measures like using weed free seeds for sowing, cleaning the farm equipments while moving it from one location to other etc can be followed.

Cultural practices like:

Crop rotations like growing legumes/crucifers/sorghum in rotations due to their allelopathic effect and competition brings shift in weed flora and control weeds. Growing cover crops like cowpea/sorghum/alfalfa which covers the ground and suppresses weed population by their resource competition.

Stale seed-bed preparations so that weed flushes can be controlled before growing of the main crop. Soil solarization by increasing the soil temperature to control weed population.

- By flooding the field.

- Sowing crops in higher density so that it has competitive advantage over weeds, should be followed. 
Conservation and use of natural enemies of weed plants should be one of the foundations of sustainable weed management so that germination of weed seeds or the spread of the established plants can be controlled in an eco-friendly way.

For example:

- Leaf beetle (Octotoma sp) feeding on Lantana camara.

- Common carp and chinese carp feeding on aquatic weeds.

- Cactoblastis sp. laying eggs on Opuntia sp.

- Rhizoctonia solani for controlling Eichornia crassipes.

From figure 1 we can observe effects of different cultural practices on weed population.

\section{Advisory support}

Family farms need tailored professional farm management advice on use of non-monetory inputs. Agriculture advisory support through organisations like KVKs, universities, various NGO's, private firms play a key role in encouraging adaptation of farm practices and technologies for interests of long term sustainability. Advisory support like:

- Timely information about current weather needs to be disseminated so that farmers can adjust their farm operations accordingly. Forewarning advisory support about weather needs to be disseminated to the farmers.

- Environment specific land-use decisions should be advised.

- Beforehand prediction about occurrence of any new diseases or pests in a particular area.

- Irrigating the lands only when fine cracks occur (intermittent drying and wetting method) and irrigating the crops in their critical growth stage period is essential.

- In areas where frost damage during night is common farmers can be advised to cover the crops with polythene.

- Soil health cards should be distributed more so that the farmers can give just the optimum fertilizers required for crop growth. (a) Faba bean

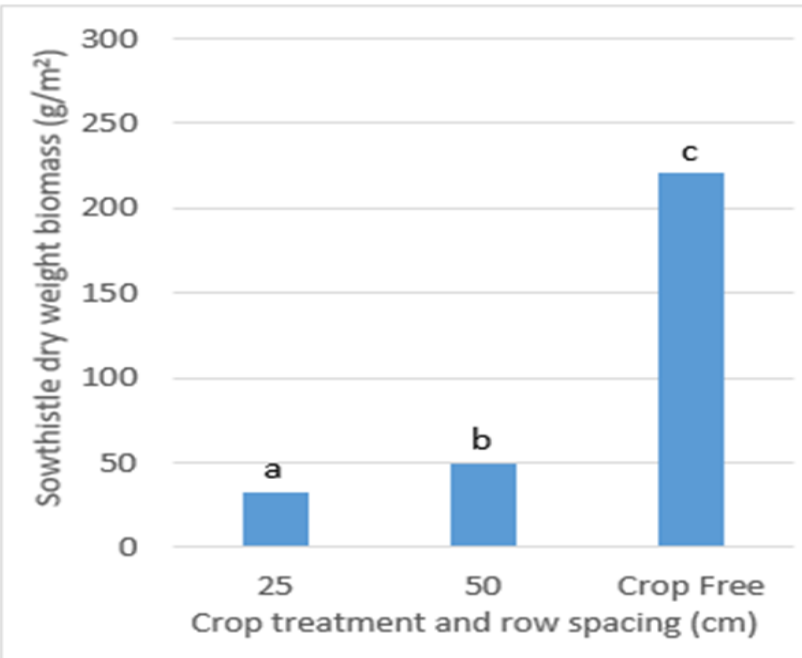

(b) Chickpea

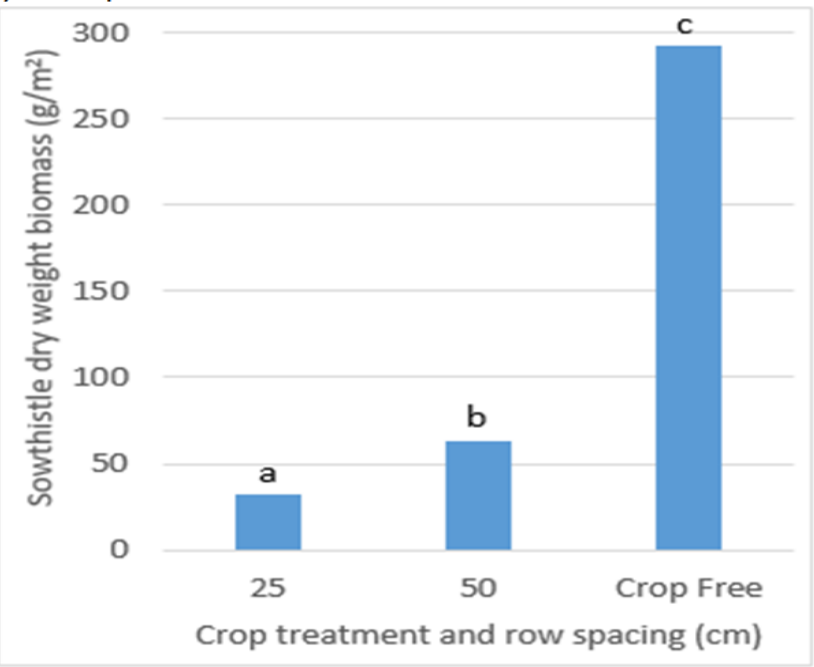

Figure.1 Sowthistle dry weight biomass $\left(\mathrm{g} / \mathrm{m}^{2}\right)$ as influenced by (a)Faba bean and

(b) chickpea row spacing $(\mathrm{cm})$ and the absence of crop. Sowthistle biomass was assessed close to crop maturity on the $9^{\text {th }}$ and $30^{\text {th }}$ October 2018 respectively. Bars with different letter within a crop are significantly different at $5 \%$ significance level 
Agriculture has become more input-intensive. People from various fronts starting from governmental and non-governmental organisations should join hands and propagate the concept and benefits of non-monetory inputs to farmers. These way small and marginal farmers can grow crops by reducing production costs at the same time benefitting the environment.

\section{References}

Abuzar, M. R., Sadozai, G. U., Baloch, M. S., Baloch, A. A. Shah, I. H., Javaid, T. and Hussain, N. 2011. Effect of plant population densities on yield of maize. The Journal of Animal \& Plant Sciences, 21(4): 692-695.

Agricultural Sustainability: Concepts, principles and evidence. 2008. Philos Trans R Soc Lond B BIOL SCI. 363(1491).

Bhattacharyya, R., Prakash, V., Kundu, S., Gupta, H.S. 2006.Effect of tillage and crop rotations on pore size distribution and soil hydraulic conductivity in sandy clay loam soil of the Indian Himalayas. Soil Till. Res. 82, 129-140.

Blum, U. L, King, T., Gerig, M., Lehman, M. and Woshen, A.D. 1997. Effects of clover and small grain cover crops and tillage techniques on seedling emergence of some dicotyledonous weed species. American J. Alter. Agric. 12, 146-161.

Dahmardeh M.2012. Effects of sowing date on the growth and yield of maize cultivars (Zea mays L.) and the growth temperature requirements. African Journal of Biotechnology Vol. 11(61), pp. 12450-12453.

FAO.fao.org/india/fao-in-india/india-at-aglance/

Ganvit, J.B., Sharma S., Surve V.H. and Ganvit ,V.C. 2019.Effect of sowing dates and crop spacing on growth, yield and quality of linseed under south Gujarat condition. Journal of Pharmacognosy and Phytochemistry 8(1): 388-392.

Gao X, Wu M, Xu R, Wang X, Pan R, Kim HJ, Liao H.2014. Root Interactions in a Maize/Soybean Intercropping System Control Soybean Soil-Borne Disease, Red Crown Rot. Plos One. 9(5).

Goitom, T., Alemtsahay, T. and Abrha, B. 2017. Effect of Organic Mulching on Soil Moisture, Yield, and Yield Contributing Components of Sesame (Sesamum indicum L.). International Journal of Agronomy. Volume 2017, Article ID 4767509, 6 pages.

Hati, K.M., Singh, R.K., Mandal, K.G., Bandyopadhyay, K.K., Somasundaram, J., Mohanty, M., Sinha, N.K., Chaudhary R.S., and Biswas, A.K. 2014. Conservation Tillage Effects on Soil Physical Properties, Organic Carbon Concentration and Productivity of Soybean-Wheat Cropping System. Journal of Agricultural Physics. Vol. 14, No. 2, pp. 121-129.

Hossain, M.A., Prodhan, M. Z. H. \& Sarker, M. A..2009. Sowing Dates: A Major Factor on the Incidence of Major Insect Pests and Yield of Mungbean. Journal of Agriculture Rural Development 7(1\&2), 127-133.

http://dwd.dacnet.nic.in/wheat_prod1/addition al_technology.htm.

http://krishikosh.egranth.ac.in/handle/1/91231 (Singh 2016).

https://www.nrcs.usda.gov/Internet/FSE_DO CUMENTS/stelprdb1254982.pdf.

https://biocyclopedia.com/index/medicinal_pl ants/production_and_management/dept h_of_sowing.php.

https://agrihunt.com/articles/basics-ofagriculture/role-of-plant-population-forcrop-productivity/.

Jat, M.L., Gathala, M.K., Ladha, J.K., Saharawat, Y.S., Jat, A.S., Sharma, 
S.K., Kumar, V. and Gupta, R.2009.Evaluation of precision land leveling and double zero-till_systems in the rice-wheat rotation: Water use, productivity, profitability and soil physical properties. SoilTill. Res.105,112-121.

Ji ,S. and Unger, P. W. 2001."Soil water accumulation under different precipitation, potential evaporation, and straw mulch conditions," Soil Science Society of America Journal, vol. 65, no. 2, pp.442-448.

Kumar,D. 2008. Influence of different planting techniques and levels of nitrogen on rice (Oryza sativa). M.Sc. Thesis, Punjab Agricultural_University, Ludhiana, Punjab, India.

Kumar,V., Sharma , J. C., Kumar, M. and Singh, S.K. 2017. Soil and plant nutrient status as modified by different types of mulching in cauliflower. Current Journal of Applied Science and Technology 24(1): 1-8.

Krenzer, E. G., Burton, R. L., Gough, F. J. 1987.Effect of crop residues on crop pests, soil water and soil temperature. Proceedings of the Southern Region No-Tillage Conference. Conservation Tillage: Today and Tomorrow. College Station, Texas, 59-62.

Lal, R. 1974. "Soil temperature, soil moisture and maize yield from mulched and unmulched tropical soils," Plant and Soil, vol. 40, no. 1, pp. 129-143.

Lal, R., Mahboubi, A.A. and Fausey, N.R., 1994. Long-term tillage and rotation effects on properties of a central Ohio soil. Soil Sci. Soc. Am. J. 58, 517-522.

Liebman, M. and Davis, A.S. 2000. Integration of soil, crop, and weed management in low-external-input farming systems. Weed Res. 40: 27-47.

Marenco, R.A. and Santos, A.M.B. 1999. Crop rotation reduces weed competition and increases chlorophyll concentration and yield of rice. Pesq. agropec. bras., Brasília, v.34, n.10, p.1881-1887.

Mikova, A.2004. Influence of the vegetation cover on the soil temperature. Plant Science, (41)216-219. In Bulgarian.

Narwal, S. S., Robert E. H., Dilday, R. H., Reigosa M. J.1998. Allelopathy in Ecological Agriculture and Forestry Proceedings of the III International Congress on Allelopathy in Ecological Agriculture and Forestry, Dharwad, India, 18-21 August 1998.

Prihar, S.S., Jalota, S.K. and Steiner, J.L.1996. Residue management for reducing evaporation in relation to soil type and evaporativity. Soil Use Manag.12, 150-157.

Putman, A.R; DeFrank, J. and Barnes, J.P. (1983). Exploitation of allelopathy for weed control in animal and perennial cropping systems. J. chemistry Ecology. 9, 1001-1010.

Salahin, N., Alam, K., Mondol, A.T.M.A.I, Islam, M.S., Rashid, M.H., Hoque, M.H. 2017. Effect of Tillage and Residue Retention on_Soil Properties and Crop Yields in Wheat-MungbeanRice Crop Rotation under Subtropical Humid Climate Open Journal of Soil Science, 7, 1-17.

Sharma, P., Singh, G., Singh, R.P. 2011. Conservation tillage, optimal water and organic nutrient supply enhance soil microbial activities during wheat (Triticum Aestivum L.) cultivation. Braz. J. Microbiol. vol.42 no. 2 .

Sharma, H.C., 2016. Climate change vis-a-vis pest management. In: Proceedings in conference on national priorities in plant health management February 4-5, 2016. Tirupati. pp. 17-25.

Sharma, R. and Bhardwaj, S. 2017. Effect of mulching on soil and water conservation -A review. Agricultural Reviews, 38(4) 2017: 311-315.

Singh, A and Kaur, J. 2012. Impact of 
conservation tillage on soil properties in rice-wheat cropping system. Agricultural Science Research Journal Vol. 2(1), pp. $30-41$

Sinkevičienè, A., Jodaugienè, D., Pupalienè R. and Urboniene M. 2009. The influence of organic mulches on soil properties and crop yield. Agronomy Research 7(Special issue I), 485-491.

The role of conservation agriculture in sustainable agriculture. 2008. Philosophical Transactions of The Royal Society Biological Sciences 363(1491): 543-55.

Valzano, F.P., Greene, R.S.B. and Murphy, B.W. 1997. Direct_effects of stubble burning on soil hydraulic properties in a direct drill tillage system. Soil Till. Res. 42, 209-219.
Weiner J.2017.Applying plant ecological knowledge to increase agricultural sustainability. Journal Of Ecology.105.865-870.

Widderick, M., McKiernan, A., Harvey, G., Heuke, L., Walsh M. and Chauhan B.2018. Deprive Weeds Of Sunlight And Space - Crop Competition Research In The Northern Grains Region. Grains Research and Development corporation(Australian government).

Yeboah, S., Zhang, R., Cai, L., Li, L. , Xie, J., Luo, Z. , Liu, J., Wu, J. 2016. Tillage effect on soil organic carbon, microbial biomass carbon and crop yield in spring wheat-field pea rotation.2016.Plant Soil Environment. vol 62 no 6.

\section{How to cite this article:}

Urjashi Bhattacharya, Smritikana Sarkar and Pintoo Bandopadhyay. 2020. Optimum Use of Nonmonetary Inputs for Sustainability in Agriculture. Int.J.Curr.Microbiol.App.Sci. 9(04): 1185-1195. doi: https://doi.org/10.20546/ijcmas.2020.904.140 